\title{
Comparative study of recurrence after pterygium excision with conjunctival autografting and amniotic membrane transplantation
}

\author{
Jain $K^{1}$, Murlimanohar J.MP2, Garg $\mathbf{P}^{3}$, Nadeem $\mathbf{M}^{4}$, Sarowa $\mathrm{S}^{5}$ \\ ${ }^{1}$ Dr. Kalpna Jain, Professor, S.P. Medical College, Bikaner, ${ }^{2}$ Dr. J.M. Murlimanohar, Professor, S.P. Medical College, \\ Bikaner, ${ }^{3}$ Dr. Payal Garg, Resident, S.P. Medical College, Bikaner, ${ }^{4}$ Dr. Muhammed Nadeem, Resident, S.P. Medical \\ College, Bikaner, ${ }^{5}$ Dr. Saroj Sarowa, Resident, S.P. Medical College, Bikaner, Rajasthan, India
}

Address for Correspondence: Dr. Kalpna Jain, C/O Dr. Dhanpat Daga, Behind SBBJ Bank, Rani Bazar Industrial Area, Bikaner (Raj.) India, Email: kalpnadaga@gmail.com

\begin{abstract}
Introduction: Pterygium is ocular surface lesion thought to originate from damage to limbal stem cells by chronic ultra violet light exposure. It has high recurrence rates following resection. Both amniotic membrane and conjunctival autograft are source of stem cells. We compare recurrence after pterygium excision with conjunctival autografting and amniotic membrane grafting. Methods: Prospective case study of seventy patients after pterygium excision with Amniotic membrane transplantation or Conjunctival autografting. Thirty five patients divided in each group and fibrin glue used for both Amniotic membrane transplantation and Conjunctival autografting. Results: Six follow up from first postoperative day to one year were done in each group. Group A (Amniotic membrane transplantation) had less Post operative complaints. In group A, all patients have well placed graft while in group B (conjunctival autografting) nine patients have graft displacement on first post operative day. It was statistically significant ( $p$ value 0.001 ). The recurrence occurring four patients in group A $(11.42 \%)$ while in 7 patients in group B $(20 \%)$. The recurrence was more in group B although it was statistically insignificant ( $\mathrm{p}$ value $<0.511$ ). Amniotic membrane transplantation with fibrin glue having less postoperative complaints, better graft stability and less recurrence as compare to conjunctival autografting. Conclusion: Our study shows good outcome with Amniotic membrane transplantation. Probably this is because of antiinflammatory property of amniotic membrane, minimum surgical trauma and uniform thickness of graft.
\end{abstract}

Keywords: Amniotic membrane transplantation (AMD), Conjunctival autografting (CAG), Fibrin glue, recurrence

\section{Introduction}

Pterygium is a triangular sheet of fibrovascular proliferation of conjunctiva that encroches the cornea. Traditionally it considered as degenerative process or disordered growth probably this occurs because of damage to limbal stem cells by chronic ultra violet light exposure. Immunohistochemical study shows the presence of p63- $\alpha$-positive epithelial cell clusters in pterygium specimens supports the hypothesis that pterygia develop from limbal epithelial progenitor [1]. The pathogenesis of pterygium is still not completely understood. An overall view of the growth process reveals multiple factors that are correlated and interrelated [2]. Multiple factors like exposure to ultra

Manuscript received $10^{\text {th }}$ June 2016

Reviewed: $19^{\text {th }}$ June 2016

Author Corrected: $30^{\text {th }}$ June 2016

Accepted for Publication $10^{\text {th }}$ July 2016 violet light, dust, wind, hot and dry climate are responsible for its development. Recent evidences implicates anti-apoptotic mechanisms, immunological mechanisms, cytokines, growth factors, extracellular matrix modulators, genetic factors and viral infections are other possible causative factors $[3,4]$.

The prevalence rates vary widely (2\% to $29 \%$ ) [5] but generally they are higher in the tropics than at temperate latitudes [6,7]. It is accepted that pterygium occurs in an equatorial belt delimited by Latitude $40 \mathrm{~N}$ and $\mathrm{S}$, associating it with ultra-violet light $[7,8]$. Prevalence increases geographically towards the equator and is greater in people exposed to outdoor environments [9]. In addition, there are associations with rural regions, increasing age and male gender, which correlate with outdoor work [10]. Pterygia are more common in men 
than in women $[9,10,11,12,13]$. The female gender has been reported as a marker for lower occupational or recreational exposure to sunlight. However, greater exposure to the sun alone cannot explain the male preponderance to developing pterygia. Probably other unknown factors also play role [12]. Epidemiological factors influencing pterygium development have been suggested (chronic sun exposure, peri-equatorial place of residence, high altitude or dry weather) $[7,11,12,14,15]$ that keeping the eyes out of direct sunlight has been beneficial. Measures such as wearing sunglasses or prescription glasses have been described as protective factors against pterygium development $[7,16,17,18]$. Patient comes due to cosmetic disfigurement, irritation, foreign body sensation, watering, redness and decrease vision. Current management options for pterygium include excision, conjunctival autografting,amniotic membrane grafting and the use of adjuvant therapies including mitomycin C, 5-fluorouracil, anti-vascular endothelial growth factor (anti-VEGF) agents, and $\beta$-irradiation.The technique of excising a pterygium without repairing the remaining defect is called bare sclera excision. This technique is no longer recommended because of its high rate of recurrence, which ranges from $38 \%$ to $88 \%$ [19]. This recurrence rate is higher than for any other treatment modality. Moreover, there are no advantages conferred by this technique except for its simplicity and short surgical time [20]. Primary closure is a technique that involves excision of the pterygium, followed by suturing of the remaining conjunctiva on either side of the wound over the bare sclera, to close the defect. This procedure has also been reported to have an unacceptably high rate of recurrence compared to newer techniques (45\%-70\%) [19]. The bare sclera and primary closure techniques both have unacceptable recurrence rates. Advances in pterygium excision have focused on the use of grafts and adjuvant therapies, of which conjunctival autografts are the most commonly used [5]. In this method, the pterygium is excised and the remaining defect closed with the patient's own grafted conjunctiva and attached using fibrin glue or sutures .An amniotic membrane (AM) graft can also be used to cover bare sclera following pterygium excision. These grafts are thought to promote healing and reduce rates of recurrence because of their anti-inflammatory properties, promotion of epithelial growth, and suppression of transforming growth factor $\beta$ (TGF- $\beta$ ) signaling and fibroblast proliferation. [19]. Recurrence rates of pterygia following amniotic membrane grafting (AMG) are cited between $14.5 \%$ and $27.3 \%$ [19]. AMG shows particular promise over the other grafting procedures in certain circumstances, such as when preexisting conjunctival scarring precludes the harvesting of donor conjunctiva for an autograft. AMG is also helpful when the superior conjunctiva must be spared for future glaucoma filtering surgery, as well as in cases of large or double-headed pterygia [21]. Adjuvant therapies, including the use of mitomycin $\mathrm{C}$, 5-flurouracil, have been used both independently and in conjunction with grafting techniques to reduce the rate of recurrence following pterygium surgery.

\section{Material and Methods}

We had perform a prospective study of 70 patients who undergone pterygium excision followed by conjunctival autografting or amniotic membrane transplantation with fibrin glue. There were two groups, each group having 35 patients. Group A undergone pterygium excision followed by amniotic membrane graft with fibrin glue. Group B underwent pterygium excision with conjunctival autografting with fibrin glue.

Most of the patients came due to ocular discomfort, watering, redness, irritation and cosmetic disfigurement. All patients had primary pterygium and informed consent of patients had taken. A complete ophthalmic examination including visual acuity, slit lamp examination, keratometery, intraocular pressure measurement, ocular movement and grading of pterygium was done. All patients had treated on outpatient basis and after preoperative evaluation, antibiotics drops were prescribed.

Group A patients undergone pterygium excision followed by amniotic membrane grafting with fibrin glue. The amniotic membrane (freeze dried) of desired size according to size of bare sclera was taken. The layer of fibrin glue was applied over bare sclera. The amniotic membrane with epithelium side up and stromal side down was placed over it. The margin of amniotic membrane graft was undermined below conjunctival margins and allowed to stic for 5 minutes. Group B patients were undergone pterygium excision followed by conjunctival autografting with fibrin glue. The conjunctival autograft were taken from superotemporal bulbar conjunctiva near limbus. Fibrin glue applied over bare sclera and conjunctival autograft was slide over bare sclera with epithelium side up and stromal side down and the limbal side of graft corresponds to limbal side of bare sclera. The margin of graft undermined and allowed to stic for 5 minutes. Graft positioning and adherence were examined at end of surgery. 


\section{Results}

The follow up of patients were done at first postoperative day, $1^{\text {st }}$ week, $1^{\text {st }}$ month, 3 months, 6 months and one year. At first postoperative day patients had redness, pain, discomfort and watering but in subsequent follow up these resolved. The total postoperative complaints were less in group A. (Table 1). Pain (p value 0.04) and redness (p value 0.001) were significantly less in Group A.

Table- 1: Distribution according to postoperative complaints

\begin{tabular}{|c|c|c|c|c|c|c|c|}
\hline \multirow[t]{2}{*}{ Groups } & \multirow{2}{*}{$\begin{array}{l}\text { Postoperative } \\
\text { complaints }\end{array}$} & \multicolumn{6}{|c|}{ Number of Cases } \\
\hline & & 1 Day & 1 Week & 1 Month & 3 Month & 6 Month & 1 Year \\
\hline \multirow{4}{*}{ Group 1} & Pain & 2 & 1 & 0 & 0 & 0 & 0 \\
\hline & Redness & 18 & 4 & 1 & 1 & 1 & 0 \\
\hline & Discomfort & 5 & 2 & 3 & 1 & 0 & 0 \\
\hline & Watering & 0 & 0 & 2 & 1 & 2 & 2 \\
\hline \multirow{4}{*}{ Group 2} & Pain & 8 & 1 & 0 & 0 & 0 & 0 \\
\hline & Redness & 31 & 14 & 0 & 0 & 1 & 3 \\
\hline & Discomfort & 5 & 8 & 5 & 3 & 5 & 5 \\
\hline & Watering & 3 & 8 & 5 & 3 & 5 & 5 \\
\hline
\end{tabular}

All patients in group A had well placed graft (Fig.1) which dissolve after one month and was replaced by growth of healthy conjunctiva in excised area.(Fig.2) In group B graft had displaced in nine patients on first postoperative day. (Fig.3) In remaining 26 patients graft was well placed. (Fig.4) The results were statistically significant with $p$ value of 0.001 (Table 2).

Table- 2: Distribution according to Graft position

\begin{tabular}{|l|l|l|l|l|l|l|l|}
\hline \multirow{2}{*}{ Groups } & Graft position on slit- & \multicolumn{4}{l|}{ Number of Cases } \\
\cline { 2 - 9 } & lamp examination & $\mathbf{1}$ Day & $\mathbf{1}$ Week & $\mathbf{1}$ Month & 3 Month & 6 Month & 1 Year \\
\hline \multirow{2}{*}{ Group 1 } & Well-placed & 35 & 35 & 35 & 35 & 35 & 35 \\
\cline { 2 - 9 } & Displaced/dislodged & 0 & 0 & 0 & 0 & 0 & 0 \\
\hline \multirow{2}{*}{ Group 2 } & Well-placed & 26 & 26 & 26 & 26 & 26 & 26 \\
\cline { 2 - 9 } & Displaced/dislodged & 9 & 9 & 9 & 9 & 9 & 9 \\
\hline
\end{tabular}

The recurrence occurred in 4 patients in group A (11.42\%) while in 7 patients in group B (20\%). Recurrence occurred more in group B but it was statistically insignificant with $\mathrm{p}$ value $<0.511$. (Table -3 )

Table-3: Distribution according to Recurrence

\begin{tabular}{|l|l|l|}
\hline Groups & $\begin{array}{l}\text { Number of patients with } \\
\text { recurrence }\end{array}$ & Percentage (\%) \\
\hline Group 1 & 4 & 11.42 \\
\hline Group 2 & 7 & 20.00 \\
\hline
\end{tabular}

This showed that amniotic membrane graft with fibrin glue had less postoperative symptoms, better graft stability that are statistically significant. The recurrence was high in conjunctival autograft although statistically insignificant. The risk of recurrence more with displacement of graft because 6 patients who develop recurrence in group B had graft displacement. This was statistically significant ( $\mathrm{p} 0.0035)$.

Three patients developed scleral necrosis which resolve with conservative treatment, probably because of excessive use of cautery. No other complications were reported. Amniotic membrane was costly product while conjunctival autograft was freely available. Amniotic membrane grafting was associated with less post operative complaints, better graft stability and less recurrence. This may be because of anti inflammatory property of amniotic membrane, minimum 
surgical trauma and proper thickness of graft . Conjunctival autograft was associated with more surgical trauma and thickness of graft also varied so more postoperative complaints, graft displacement and recurrence as compared to amniotic membrane.

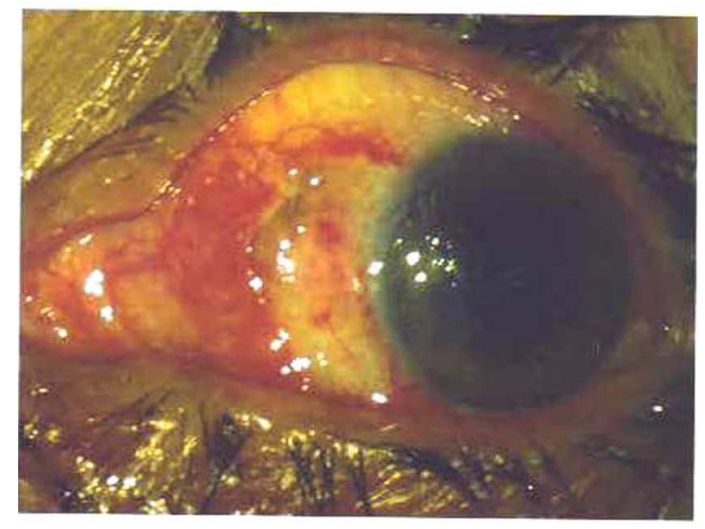

Fig-1: Amniotic membrane graft with fibrin glue, at 1 week postoperative showing well placed graft

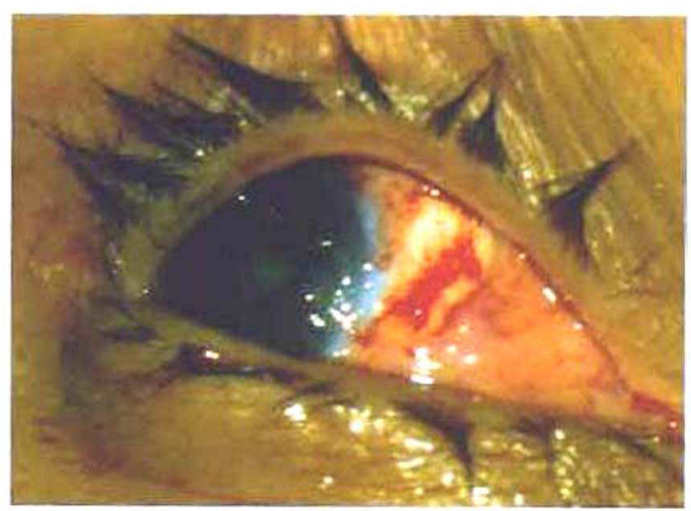

Fig-3: Conjunctival autograft with fibrin glue, at 1day postoperative showing dislodged graft

\section{Discussion}

A pterygium is a wing like mass of fibrovascular tissue extending from conjunctiva to the cornea. Histopathologically the pterygium is elastotic degeneration of conjunctiva. Epithelium may be normal, acanthotic, hyperkeratotic or even dysplastic. Impression cytology of surface cells directly overlying pterygium is abnormal, showing increased goblet cell density with squamous metaplasia.

The substantia propria shows elastotic degeneration of collagen as defined by Austin et al [22] as elastodysplasia and

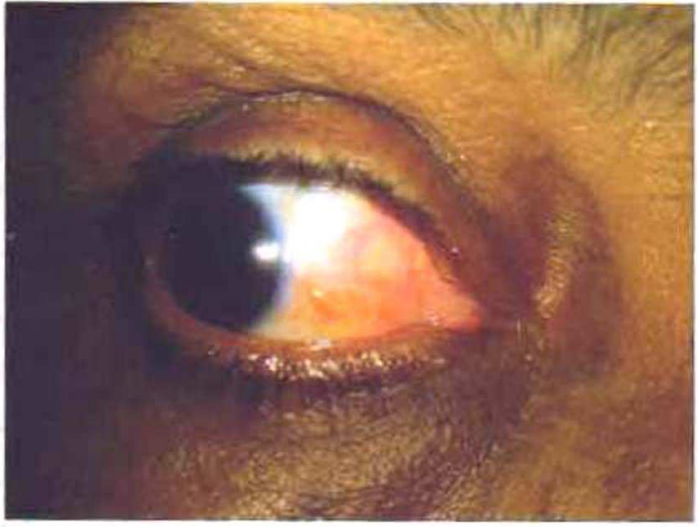

Fig-2: Amniotic membrane graft with fibrin glue at 1 monhts postoperative showing dissolution of amniotic membrane with growth of normal healthy conjunctiva

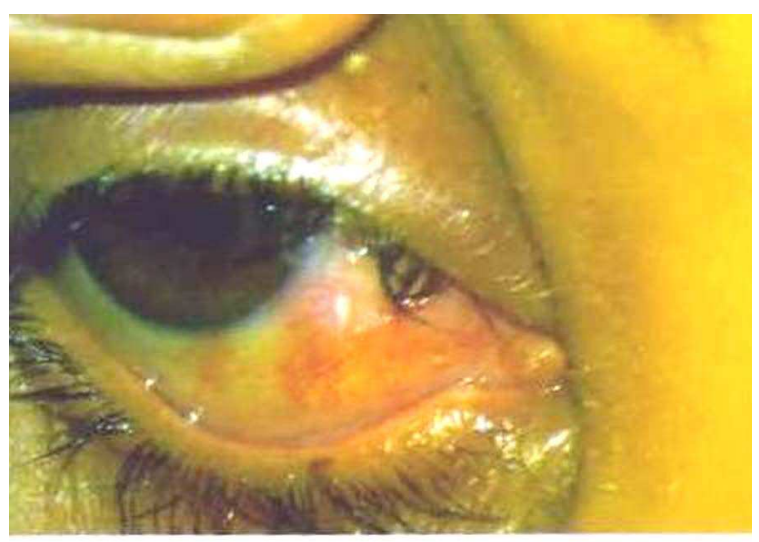

Fig-4: Conjunctival autograft with fibrin glue, at 1 week postoperative showing well placed graft elastodystrophy. Collagen being produced undergoes abnormal maturation and degeneration. The source of the fibers is thought to be from damaged fibroblasts. Pterygia have three distinct parts. The cap of leading edge is a flat, gray zone on the cornea consisting mainly of fibroblasts. This area invades and destroys Bowman's layer. An iron line (Stocker's line) may be seen anterior to the cap, where tear flow is abnormal. Immediately behind the cap is a whitish, thickened vascular area firmly attached to cornea, referred to as head. The body or tail is the fleshy, mobile, vascular area of bulbar conjunctiva, which has distinct edges. 
Exact etiology is not known. It is thought to be originating from limbal stem cells altered by chronic ultra violet light exposure. The presence of p63- $\alpha$ positive epithelial cell clusters supports the hypothesis that pterygia develop from limbal epithelial progenitors [1]. The p63 is especially important for the development of epidermis and its derivatives. Later in development and in adults, p63 $\alpha$ becomes confined to the basal layer and marks keratinocyte stem cells. The balance of p63 isoforms, together with the presence or absence of the other p53 family members, p73 and p53, has a striking biological impact. Conventionally regarded as a degenerative condition, but newer theories postulate that pterygia also display tumor-like features. These includes propensity to invade normal tissue, high recurrence rates following resection, ultra violet radiation exposure as an etiology and common treatment modalities (radiation and antimetabolites) and may coexist with secondary premalignant lesions. The p53 gene is located on the short arm of chromosome seventeen and its main function is as a tumor suppressor gene. The gene is known to control cell differentiation, cell cycle and apoptosis. Mutations in the p53 gene inactivate or alter its functions. These mutations are the most common genetic marker of human neoplastic growth. The abnormal p53 expression in the epithelium of pterygia raises the possibility that it may be a growth disorder due to uncontrolled cell proliferation rather than a degenerative disorder [23]. There have been theories of microtrauma induced by sand, dust, wind or drying. Probably its occurrence is multifactorial and may include hereditary susceptibility. It is present in interpalpebral area and more common nasally then temporally. The nasal predominance is probably due to increased UV damage in this area. One theory suggest reflection of UV light of the side of the nose while other says cornea itself act like a side - on lens to focus UV light into this area. Pterygium can be quiescent with little vascularity and no observed growth. They can be active with hyperemia and fairly rapid growth. Patients may be asymptomatic. Most often, the patient comes either worried about the cosmetic appearance or symptomatic with redness, irritation, foreign body sensation, photophobia or visual changes. Decreased vision can occur as the pterygium crosses the visual axis or induce astigmatism. A tethering effect may be created by large lesions causing diplopia, most commonly in lateral gaze. This effect will occur more often in recurrent lesions with scar tissue formation.

Pterygia have geographical predisposition in periequatorial region. The epidemiological study also shows its correlation to UV radiation, hot, dry, sunny and sandy climate. It is commonly seen in age group 20-40 years, twice common in males than females and in outdoor workers. It is seen more frequently in certain populations, and its incidence varies greatly in different geographical zones. Pterygium was seen twice as frequent among persons who worked outdoors but was only one fifth as likely among those who always used sunglasses outdoors.[24] In the Barbados eye studies, the incidence of pterygium was high in black population, for an average of $1.3 \%$ per year. Working outdoors increased the risk 1.5-fold, whereas having a darker skin complexion and using eyewear for either reading or distance substantially decreased the risk of developing pterygium [25].

It is endemic in South East Asia, Maxico, Australia, and in Eskimoes. In India, it is more prevalent in Rajasthan and Laddakh. The effective treatment is surgery. However, none of surgical procedure is perfect and universally accepted because recurrence is quiet common. The recurrence usually occurs in 4 month to one year. Various factors like fibroblastic activity, inflammation and vascularization may play role in recurrence. The various surgical indications are reduced visual acuity either due to irregular astigmatism or encrochments of pterygium on visual axis, restricted ocular motility or cosmesis. There are various techniques like bare sclera technique, redirection of pterygium head, pterygium excision with conjunctival autografting or amniotic membrane grafting, use of antimetabolites and beta radiation to prevent recurrence.

At the corneo-scleral limbus there is a gradual transition from the stratified, non keratinised squamous epithelium of the cornea to the stratified, nonkeratinised columnar epithelium with mucin-secreting goblet cells of the conjunctiva. It has 7-10 layers of cells, which have attachments similar to the corneal cells. The architecture of the limbus demonstrates a palisade (of Vogt) arrangement. The limbal stem cells probably reside in the basal layer of the palisades of Vogt [26]. When there is a demand for tissue regeneration, the stem cells divide. When a stem cell divides, one of the daughter cells remains as a parent and serves to replenish the stem cell pool, whereas the other daughter cell is destined to divide and differentiate, acquiring features that characterise the corneal epithelium. Such daughter cells are called "transient amplifying cells"and are distributed in the corneal basal cell layer. The transient amplifying cells migrate centripetally and after a high but limited number of mitoses, they further differentiate to "post-mitotic cells" which do not divide 
any further. These post-mitotic cells ultimately differentiate into terminally differentiated cells which die after a certain time. The stem cells are located exclusively in the limbal basal epithelium. The occurrence of transient amplifying cells is limited to the basal layer of limbal and corneal epithelia. Post-mitotic and terminally differentiated cells make up the superficial layers of limbal and corneal epithelia [27]. These studies confirm that the limbal epithelium contains a population of slow-cycling cells that display the characteristics of stem cells. Limbal stem cells are shown to be abundant in the superior and inferior limbus as compared with the temporal and nasal limbus. Limbal stem-cell deficiency can be primary, related to an insufficient stromal microenvironment to support stem cell function or secondary (more common) related to external factors that destroy limbal stem cells. Corneal stem-cell deficiency can be diffuse (total) or sectoral (partial). In the latter case conjunctivalisation of the corneal epithelium affects only part of the corneal surface. In some patients, limbal deficiency may be subclinical at the time of the insult, and may eventually progress to an overt stage of limbal deficiency as the stem cell population depletes further, over time. If the conjunctival stem cells (presumed to be in the fornices) $[28,29]$ are also depleted, which is rare because of the larger area they occupy than ocular surface eventually is covered by totally keratinised epithelium, which sometimes may be seen at the end stage of OCP or Stevens-Johnson syndrome.

Mechanical debridement of conjunctiva-like epithelium and encouraging the denuded area to be resurfaced with corneal epithelial cells is a valid and simple alternative to limbal transplantation in patients with partial limbal stem cell deficiency. Varied surgical procedures have been described for the treatment of pterygium. The high postoperative recurrence rates indicate that there is still no single definitive treatment. The ideal surgical technique should be one that effectively prevents recurrences without development of complications. Of the procedures used most often, the one that comes closest to achieving this goal is, probably, the conjunctival autograft described by Kenyon et al [30]. This procedure reduces recurrence with minimal complications when compared with the use of $\beta$ radiation or mitimycin-c. The conjunctival transplantation to treat corneal stem cell deficiency was supported by the belief that conjunctival epithelium "transdifferentiates" into cornea-like epithelium [31]. However, recurrences were not completely eliminated, especially in patients who live in areas with high levels of ultraviolet light. Tseng et al [32]. had successfully used amniotic membrane transplantation (AMT) and mechanical debridement and advocate its use to treat patients with partial stem cell deficiency. Their study showed that with partial or focal limbal stem cell deficiency, AMT improves both the corneal surface and the vision.Amniotic membrane grafts has been used to create a limbal barrier in pterygium surgery [33]. The amniotic membrane is a thick basement membrane and a vascular stromal matrix. These features are crucial to successful transplantation. The basement membrane facilitates migration of epithelial cells, reinforces adhesion of basal epithelial cells and promotes epithelial differentiation. The basement membrane is also important to prevent apoptosis. As only the substrate without cells is employed, there is no adverse reaction of rejection

Graft can be placed either with fibrin glue or sutures. Suturing is a time consuming process. An ideal suture is one which is easy to handle, non-allergenic, affordable and does not promote infection. None of the sutures currently available fulfill the requirements of an ideal suture. To overcome these shortcomings, tissue adhesives are being increasingly used. Fibrin glue is a biological tissue adhesive which imitates the final stages of the coagulation cascade when a solution of human fibrinogen is activated by thrombin (the two components of fibrin glue). Fibrin glue includes a fibrinogen component and a thrombin component, both prepared by processing plasma. The commercially available products are produced from pools of plasma, usually contain high yields of fibrinogen and, consequently, produce firm coagulum. Fibrin glue forms a smooth seal along the entire length of the wound edge and thereby provides greater postoperative comfort to the patient with fewer complications. It is a safe and effective method for attaching conjunctival autografts for wound closure following pterygium surgery. Its use results in a shorter operating time, less post operative discomfort and inflammation. Jiang et al. in 2008 evaluated the efficacy and safety of fibrin glue in conjunctival autograft fixation in primary pterygium compared with that of suturing [34]. They found that fibrin glue application takes significantly shorter operating time and associated with fewer post operative symptoms than a sutured graft, indicating the safety of the procedure. Studies have also demonstrated its efficacy for amniotic membrane graft fixation during pterygium surgery in terms of reduction of surgical time and post operative discomfort. In our study we use 
amniotic membrane or conjunctival autograft with fibrin glue after pterygium excision.

Di Girolamo (2001) suggested that possibility of damage to limbal stem cells by ultra violet light and activation of matrix metalloproteinase leads to development of pterygium [35]. Amniotic membrane and conjunctival autograft are probable source of stem cells. Kenoyn (1985) used superotemporal bulbar conjunctival autograft and found low recurrence rate (5.3\%) [30] but result varied worldwide. C Kuckerdurez (2008) was compare use of fibrin glue and sutures for placement of conjunctival autograft. He found pterygium recurrence in fibrin glue group was $4 \%$ and suture group was $12 \%$ [36]. Pulte et al (1998) [37], Rao S.K. et al (1998) [38], Malik et al (2012) [39], Jiang J (2008) [34], Sarnicola (2010) [40] reported a recurrence rate of $2.85 \%, 3.8 \%, 2.5 \%, 5 \%$ and $4.5 \%$ respectively after limbal conjunctival autografting while Wong et al (2000) experienced higher reccurance rate $(18.2 \%)$ after inferior limbal conjunctival autografting in recurrent pterygium [41]. Ivekovic et al (2001) recorded recurrence rate of $15.4 \%$ with amniotic membrane transplantation [42].

Shao $\mathrm{Y}$ et al evaluate in nine patient with AMT or conjunctival autografting with fibrin glue with very good results [43]. Asadollah Katbaab et al (2008) also reported low recurrence rate $(2 \%)$ in primary pterygium excision with AMT [44]. Amniotic membrane closure and conjunctival autografts seem to be equally effective in the prevention of recurrence of primary pterygium. Due to the larger area of subconjunctival fibrosis, a larger defect area is created after the excision of pterygium tissue and a larger graft is needed to close this defect in recurrent pterygium. This factor can guide the surgeon during the planning of the surgery to choose the most appropriate technique for closure of the defect.

In different studies recurrence rate varies with both AMT or CAG. The recurrence rate after pterygium excision with amniotic membrane transplantation was $11.42 \%$ while after conjunctival autografting recurrence was $20 \%$ in our study. Amniotic membrane promotes growth of normal healthy conjunctiva in bare sclera, provide favorable conditions for limbal stem cells to multiply reduce inflammatory scarring and vascularization and hence reduce the risk of recurrence and graft displacement. Fibrin glue is associated with lower surgical time, smooth seal along the entire length, no tissue reaction as compare to sutures.

\section{Conclusion}

Graft stability and postoperative complaints less with amniotic membrane graft as compare to conjunctival autograft. This is statistically significant. The recurrence was also less with amniotic membrane graft, but it is not statistically significant. The conjunctival autograft was associated with more surgical trauma and thickness of graft also varied. So, amniotic membrane is better alternative as compare to conjunctival autograft. This may be because of anti-inflammatory property of amniotic membrane, minimum surgical trauma and uniform thickness of amniotic membrane graft. It is also helpful for preserving donor bulbar conjunctiva for future surgery.

Funding: Nil, Conflict of interest: None initiated, Permission from IRB: Yes

\section{References}

1. Chui J, Coroneo MT, Tat LT, Crouch R, Wakefield D, Di Girolamo N. Ophthalmic pterygium: a stem cell disorder with premalignant features. Am J Pathol. 2011 Feb;178(2):817-27. doi: 10.1016/j.ajpath.2010.10.037.

2. Solomon AS. Pterygium. Br J Ophthalmol. 2006 Jun;90(6):665-6.

3. Bradley JC, Yang W, Bradley RH, Reid TW, Schwab IR. The science of pterygia. Br J Ophthalmol. 2010 Jul;94(7):815-20. doi: 10.1136/bjo.2008.151852. Epub 2009 Jun 9.

4. Song YS, Ryu YH, Choi SR, Kim JC. The involvement of adult stem cells originated from bone marrow in the pathogenesis of pterygia. Yonsei Med J. 2005 Oct 31;46(5):687-92.

5. Ang LP, Chua JL, Tan DT. Current concepts and techniques in pterygium treatment. Curr Opin Ophthalmol. 2007 Jul;18(4):308-13.

6. Gazzard G, Saw SM, Farook M, Koh D, Widjaja D, Chia SE, Hong CY, Tan DT. Pterygium in Indonesia: prevalence, severity and risk factors. Br J Ophthalmol. 2002 Dec;86(12):1341-6.

7. Luthra R, Nemesure BB, Wu SY, Xie SH, Leske $\mathrm{MC}$; Barbados Eye Studies Group. Frequency and risk factors for pterygium in the Barbados Eye Study. Arch Ophthalmol. 2001 Dec;119(12):1827-32.

8. Vojniković B, Njirić S, Coklo M, Toth I, Spanjol J, Marinović M. Sunlight and incidence of pterygium on 
Croatian Island Rab--epidemiological study. Coll Antropol. 2007 Jan;31 Suppl 1:61-2.

9. Ti SE, Tseng SC. Management of primary and recurrent pterygium using amniotic membrane transplantation. Curr Opin Ophthalmol. 2002 Aug;13(4):204-12.

10. Ma K, Xu L, Jie Y, Jonas JB. Prevalence of and factors associated with pterygium in adult Chinese: the Beijing Eye Study. Cornea. 2007 Dec;26(10):1184-6.

11. Janson BJ, Sikder S. Surgical management of pterygium. Ocul Surf. 2014 Apr;12(2):112-9. doi: 10.1016/j.jtos.2014.01.001. Epub 2014 Jan 31.

12. West S, Muñoz B. Prevalence of pterygium in Latinos: Proyecto VER. $\mathrm{Br}$ J Ophthalmol. 2009 Oct;93(10):1287-90. doi: 10.1136/bjo.2008.152694. Epub 2009 Jun 30.

13. McCarty CA, Fu CL, Taylor HR. Epidemiology of pterygium in Victoria, Australia. Br J Ophthalmol. 2000 Mar;84(3):289-92.

14. Kandavel R, Kang JJ, Memarzadeh F, Chuck RS. Comparison of pterygium recurrence rates in Hispanic and white patients after primary excision and conjunctival autograft. Cornea. 2010 Feb;29(2):141-5. doi: 10.1097/ICO.0b013e3181b11630.

15. Moran DJ, Hollows FC. Pterygium and ultraviolet radiation: a positive correlation. Br J Ophthalmol. 1984 May;68(5):343-6.

16. Threlfall TJ, English DR. Sun exposure and pterygium of the eye: a dose-response curve. Am J Ophthalmol. 1999 Sep;128(3):280-7.

17. Al-Bdour M, Al-Latayfeh MM. Risk factors for pterygium in an adult Jordanian population. Acta Ophthalmol Scand. 2004 Feb;82(1):64-7.

18. Mackenzie FD, Hirst LW, Battistutta D, Green A. Risk analysis in the development of pterygia. Ophthalmology. 1992 Jul;99(7):1056-61.

19. Moran DJ, Hollows FC. Pterygium and ultraviolet radiation: a positive correlation. Br J Ophthalmol. 1984 May;68(5):343-6.

20. Alpay A, Uğurbaş SH, Erdoğan B. Comparing techniques for pterygium surgery. Clin Ophthalmol. 2009;3:69-74. Epub 2009 Jun 2.
21. Solomon A, Pires RT, Tseng SC. Amniotic membrane transplantation after extensive removal of primary and recurrent pterygia. Ophthalmology. 2001 Mar;108(3):449-60.

22. Austin P, Jakobiec FA, Iwamoto T. Elastodysplasia and elastodystrophy as the pathologic bases of ocular pterygia and pinguecula. Ophthalmology. 1983 Jan;90(1):96-109.

23. Weinstein O, Rosenthal G, Zirkin H, Monos T, Lifshitz T, Argov S. Overexpression of p53 tumor suppressor gene in pterygia. Eye (Lond). 2002 Sep;16(5):619-21.

24. Luthra R, Nemesure BB, Wu SY, Xie SH, Leske MC; Barbados Eye Studies Group. Frequency and risk factors for pterygium in the Barbados Eye Study. Arch Ophthalmol. 2001 Dec;119(12):1827-32.

25. Nemesure B, Wu SY, Hennis A, Leske MC; Barbados Eye Studies Group. Nine-year incidence and risk factors for pterygium in the barbados eye studies. Ophthalmology. 2008 Dec;115(12):2153-8. doi: 10.1016/j.ophtha.2008.08.003. Epub 2008 Oct 18.

26. Davanger M, Evensen A. Role of the pericorneal papillary structure in renewal of corneal epithelium. Nature. 1971 Feb 19;229(5286):560-1.

27. Kruse FE. Stem cells and corneal epithelial regeneration. Eye 1994; 8:170-183; doi: 10.1038/eye. 1994 .

28. Wei ZG, Wu RM, Lavker R, Sun TT. In vitro growth and differentiation of rabbit bulbar fornix and palpebral conjunctival epithelia. Implications on conjunctival epithelial transdifferentiation and stem cells. Invest Ophthalmol Vis Sci. 1993; 34(5):1814-28.

29. Coster DL, Aggarwal RK, Williams KA. Surgical management of ocular surface disorders using conjunctival and stem cells allografts. $\mathrm{Br} \quad \mathrm{J}$ Ophthalmol. 1995; 79(11):977-82.

30. Kenyon KR, Wagoner MD, Hettinger ME. Conjunctival autograft transplantation for advanced and recurrent pterygium. Ophthalmology, 1985; 92(11):1461-70.

31. Tseng SCG, Hirst LW, Farazdaghi M, Green WR. Goblet cell density and vascularization during conjunctival transdifferentiation. Investigative 
Ophthalmology \& Visual Science October 1984; (25):1168-1176.

32. Tseng SCG, Prabhasawat P, Barton K, Gray T, Meller D. Amniotic membrane transplantation with or without limbal allografts for corneal surface reconstruction in patients with limbal stem cell deficiency. Arch Ophthalmol. 1998; 116(4):431-41.

33. Prabhasawat P, Barton K, Burkett G, Tseng SC. Comparison of conjunctival autograft, amniotic membrane, and primary closure for pterygium excision. Ophthalmology.1997; 104(6):974-85.

34. Jiang J, Yang Y, Zhang M, Fu X, Bao X, Yao K. Comparison of fibrin sealant and sutures for conjunctival autograft fixation in pterygium surgery:one year follow-up. Ophthalmologica. 2008; 222(2):105-11. doi: 10.1159/000112627. Epub 2008 Feb 22.

35. Di Girolamo N, Chui J, Coroneo MT, Wakefield D. Pathogenesis of pterygium: role of cytokines, growth factors and matrix metallolproteinases. Prog Retin Eye Res. 2004; 23(2):195-228.

36. A Karalezli, C Kucukerdonmez, Y A Akova, R Altan-Yaycioglu, M Borazan. Fibrin glue versus suture for conjunctival autografting in pterygium surgery: A prospective comparative study. Br J Ophthalmol 2008; 92:1206-1210 doi:10.1136/bjo.2008.139600

37. Pulte $\mathrm{P}$, Heiligenhaus A, Koch J, Steuhl KP, Waubke T. Long term results of autologus conunctival limbal transplantation. Klinische Monatsblatter fur Augenheilkunde..1998; 213(1):9-14.

38. Srinivas K Rao, T Lekha, Bickol N Mukesh, G Sitalakshmi, Prema Padmanabhan. Conjunctival limbal autograft for primary and recurrent pterygium : technique and results. IJO 1998; 46(4):203-209.

39. Malik KP, Goel R, Gupta A, Gupta SK, Kamal S, Mallik VK, Singh S. Efficacy of sutureless and glue free limbal conjunctival autograft for primary pterygium surgery. Nepal J Ophthalmol. 2012; 4(2):230-5. doi: http://dx.doi.org/10.3126/nepjoph.v4i2.6537.

40. Sarnicola V, Vannozzi L, Motolese PA. Recurrence rate using fibrin glue-assisted ipsilateral conjunctival autograft in pterygium surgery: 2 years follow up. Cornea. 2010;29(11):1211-4. doi: 10.1097/ICO.0b013e3181d5d96d.

41. AK Wong, SK Rao, AT Leung, AS Poon, DS Lam. Inferior limbal conjunctival autograft transplantation for recurrent pterygium IJO 2000; 48(1):21-4.

42. Ivanka Petric, Renata Iveković, Dean Šarić, Zoran Vatavuk, Zdravko Mandić. Amniotic membrane transplantation for ocular surface reconstruction. Acta clinica Croatica, 2002; 41(4):23-28.

43. Yi Shao, Xin Zhou, Yao Yu, Chong-Gang Pei, Qiong Zhou, Juan Li, Lu Yang, Wen-Jia Dong, Jing-Lin Yi. Novel sutureless transplantation for primary pterygium associated with cysts. Int $\mathrm{J}$ Ophthalmol. 2011 ; 4(3) : 280-283. doi: 10.3980/j.issn.22223959.2011.03.14

44. Asadollah Katbaab, MD, Hamid-Reza Anvari Ardekani, MD, Hamid Khoshniyat, MD, and HamidReza Jahadi Hosseini, MD. Amniotic membrane transplantation for primary pterygium surgery. J Ophthalmic Vis Res. 2008; 3(1): 23-27.

\section{How to cite this article?}

Jain K, Murlimanohar J.M, Garg P, Nadeem M, Sarowa S. Comparative study of recurrence after pterygium excision with conjunctival autografting and amniotic membrane transplantation. Int J Med Res Rev 2016;4 (7):12811289.doi:10.17511/ijmrr.2016.i07.35. 